\title{
CORRESPONDENCE
}

Correspondents are asked to be brief

Superannuation and Substandard Lives

K. D. Allardyce, M.B................... 165

Overdosage of Tetracosactrin in Rheumatoid Arthritis

F. Dudley Hart, F.R.C.P., and others....... 165

Osteoporosis and Exercise

A. W. Fowler, F.R.C.S................... 165

Halothane Hepatitis

Abdominal Aortic Aneurysm and Peptic Ulcer

G. J. Prockter, F.R.C.S.................. 166

Streptococcal Meningitis

Coutinho, D.T.M.\&H. ......................166

Nature's Transplant

J. M. Anderson, F.R.c.s., and M. A.

Ferguson-Smith, M.R.C.PATH

Antibacterial Agents in Renal Failure

J. McC. Murdoch, F.R.C.P.ED...........167

Drugs in Schizophrenia

P. A. J. Janssen, M.D.

Methotrexate, Alcohol, and Liver Damage

J. J. R. Almeyda, M.R.C.P., and others.....167

Genetic Cripples

N. J. Gross, PH.D., M.R.C.P............ 167
J. D. Hill, F.F.A.R.C.S.................. 166

S. M. Hempling, M.B., and M. de L. P.
Encouraging Recruits to Medicine

R. D. Clegg; M. J. World, B.SC..........168

Uneasy Relations

J. W. Dundee, M.D., F.F.A.R.C.S.............168

Restless Legs

M. Weller, M.A.

Clinical Research in General Practice

C. Maxwell, M.B.

Special Groups in Tuberculosis

I. Sutherland, D.PHIL............

Septic Gonococcal Dermatitis

J. R. W. Harris, M.R.C.P., and others.....169

\section{Rheumatoid Neuropathy}

J. R. Golding, D.M.; D. N. Golding,

F.R.C.P.I. . ............................... 169

A Case of Confidence

D. L. Williams, M.B.; R. L. McKechnie,

M.B.; W. K. E. Bernfeld, M.D............169

R.C.S. Council

D. H. Patey, F.R.c.s................. 170

Aerosols in Asthma

L. H. Harris, M.R.C.P.ED.............. 170

Self-certification

J. L. Kearns, D.I.H. .
Physicians for Chest Diseases

D. Davies, F.R.C.P.................... 170

Hypertension during Chlorimipramine

Therapy

G. H. Collins, D.P.M.

Family Doctor Booklet

I. Oswald, M.D.; T. E. T. Weston, M.D...171

Ulcerative Colitis

Linda Beeley, M.R.C.P., and R. H. Leach,

M.P.S. ..................................171

School Health Service

C. D. L. Lycett, M.D., D.P.H.

Secrecy over Hospital Closures

J. A. Ross, F.R.C.P.ED....

Radiologists' Terms of Service

J. Ainsworth, M.D., F.F.R.R.C.S.I., and

others; A. G. M. Davies, M.D., D.M.R.D...172

Keeping on the "Medical Register"

W. J. Appleyard, M.R.C.P................ 172

G.M.C.'s Functions and the B.M.A.

I. M. Quest, M.B........................ 172

G.M.C. Election

P. L. Loveridge, м.в................. 172

Inflation and the N.H.S.

A. H. Bacon, M.B....

\section{Superannuation and Substandard Lives}

SIR,-I am prompted to write this letter by the experience of a patient of mine. This man, aged 30 , had rheumatic fever as a child leaving him with aortic and mitral valvular lesions. His cardiac state is, however, so well compensated that he took part in athletics at school and is still more than usually physically active. He has a dynamic, thrusting personality but has now been reduced to a state of chronic frustration by the apparent tyranny of superannuation rules. Clearly such a substandard life cannot be acceptable in the normal type of business superannuation scheme but need this apply an absolute ceiling to promotion above the most junior managerial level ?

There appears to be no flexibility in the application of superannuation medical standards. This man, for example, has been trying now for several years to achieve promotion, receiving interview after interview all over the country, being regularly accepted for the job and just as regularly turned down because he is a substandard life. Ironically people of his

type rarely stay longer than a few years in one job, and any firm which had felt able to employ him over the past few years could already have safely done so. This described the creation of "substandard

\section{Overdosage of Tetracosactrin in Rheumatoid Arthritis}

SIR,-In the ten years after the introduction of cortisone and its analogues into clinical practice many patients were seen suffering not so much from their original disease as from a disorder compounding drug-induced Cushing's syndrome with rheumatoid arthritis. Overdosage was common and it took the profession several years to discover the correct conservative dose of oral corticosteroids in rheumatoid arthritis.

This same problem of overdosage is now often caused by the synthetic corticotrophin, tetracosactrin (Synacthen, Cortrosyn). The development of this compound has been a considerable therapeutic advance. In its
As long ago as 1957 the B.M.F. published a report on underwriting substandard lives. pools", e.g., for hypertensives, as a means of extending life cover to them. Is it not possible that similar substandard pools applied to superannuation insurance might provide a way around the problem?

It seems to me a daunting thought that as medical screening becomes more popular, more people may find themselves "substandard". Surely we as a profession owe it to them to see that inflexible application of superannuation criteria does not inevitably block the careers of otherwise able people.I am, etc.

KenNeth D. AllaRdyce

Scunthorpe, Lincs

Shirley Smith, K., British Medical fournal, 1957, 2

the dose to $0.5 \mathrm{mg}$ daily a plasma cortisol level was $146 \mu \mathrm{g} 100 \mathrm{ml}$ and 24-hour urinary free cortisol excretion was 16,484 $\mu \mathrm{g}$. Galvão-Teles and others ${ }^{1}$ state that the urinary free cortisol response to $1 \mathrm{mg}$ Synacthen depot suggests that with normal adrenals the exposure of tissues to nonprotein-bound cortisol is increased 30-fold over the 24 hours after injection.

We find in the treatment of rheumatoid arthritis that most patients need a daily injection of tetracosactrin depot to control their symptoms. We start treatment with 0.1 to $0.2 \mathrm{mg}$ daily, adjusting the dose later as required. Daily maintenance doses are usually less than $0.1 \mathrm{mg}$. The availability of a more dilute solution would make the injection of these small doses somewhat easier. -We are, etc.,

F. Dudley Hart R. T. TAYLOR

E. C. Huskisson

Westminster Hospital, Gillian M. SHENFIELD

London S.W.1

Galvao-Teles, A., Burke, C. W., and Fraser, T. R.,

\section{Osteoporosis and Exercise}

clinical application, however, dosage has often been too high with inevitable Cushingoid sequelae. Synacthen depot contains $1 \mathrm{mg}$ of tetracosactrin in $1 \mathrm{ml}$ of a zinc phosphate complex. Though the makers advise $0.5-1 \mathrm{mg}$ intramuscularly twice weekly, or less frequently, it is often given daily, sometimes in a dose of $1 \mathrm{mg}$ or more for a considerable time. We have recently seen the effects of this daily dosage in several patients. One particular patient had been receiving $3.5 \mathrm{mg}$ tetracosactrin daily. She had Cushingoid facies, hypertension, posterior subcapsular cataracts, and diabetes mellitus. Even after reduction of

SIR,-In his detailed analysis of the causes of March, p. 571) discusses nutritional and hormonal factors but makes no mention of the key factor-namely, lack of exercise. This is hinted at in your leading article (p. 566) when you mention the harmful effects of immobilization and advise graduated spinal exercises to improve muscle power. You remind us of the "dowagers hump" sign-an appropriate description because the dowager takes very little exercise.

Professor Nordin must be familiar with the experimental work of Geiser and Trueta ${ }^{1}$ who Lancet, 1971, 1, 557 . osteoporosis Professor B. E. C. Nordin (13 